\title{
NILAI FILOSOFIS \\ BUDAYA MATRILINEAL DI MINANGKABAU (RELEVANSINYA BAGI PENGEMBANGAN HAK-HAK PEREMPUAN DI INDONESIA)
}

\section{Iva Ariani}

Fakultas Filsafat, Universitas Gadjah Mada, Yogyakarta

Email: iva.ariani@yahoo.co.id

\section{Abstrak}

Penelitian ini adalah penelitian kualitatif untuk menemukan esensi budaya matrilineal adat Minangkabau menurut Filsafat Feminisme. Metode pengumpulan data yang digunakan dalam penelitian ini adalah dengan membagi daerah penelitian di Sumatera Barat ke dalam dua kelompok besar yaitu Minang Pesisir dan Minang Bukit. Selanjutnya peneliti mengumpulkan data melalui wawancara dan observasi langsung ke daerah tersebut untuk mendapatkan bukti dan data tentang sistem matrilineal di Sumatera Barat. Data yang sudah terkumpul kemudian dianalisis dengan menggunakan metode interpretasi dan hermeneutika yang selanjutnya dijabarkan ke dalam suatu konsep yang dapat dipakai sebagai bahan masukan bagi perkembangan proses penegakan hak-hak perempuan di Indonesia. Penelitian ini bermanfaat bagi perkembangan gerakan-gerakan wanita dan undang-undang tentang kewanitaan di Indonesia dari sisi yang lebih sesuai dengan kepribadian dan budaya masyarakat Indonesia sendiri karena diangkat dari kearifan lokal dan budaya lokal masyarakat Indonesia sehingga diharapkan akan lebih sesuai dalam rangka menawarkan nilainilaifeminis yang sesuai untuk masyarakat Indonesia.

Kata Kunci: Minangkabau, matrilineal, feminisme.

\section{Abstract}

This research is a qualitative research to find an essence of matrilineal culture in Minangkabau tradition from the philosophical perspective of Feminism. Method of data collection is dividing research areas in West Sumatra into two big groups that are Minang Pesisir and Minang Bukit. Then, collecting data through direct interview and observation to get data about matrilineal system in West Sumatra. Data which has collected then be analyzed using interpretation and hermeneutics method and described as a concept to develop the rights of enforcer process of woman in Indonesia. This research is to develop the woman movements and law concerning femininity in Indonesia that is more suitable with the personality and cultural of Indonesia because it lifted from local and cultural wisdom in Indonesia. The expectation is that it will be able to more 
suitable to the agenda of offering values of feminist appropriate for public of Indonesia.

Keywords: Minangkabau, matrilineal, feminism.

\section{PENDAHULUAN}

Hak asasi adalah hak yang dimiliki manusia yang telah diperoleh dan dibawanya bersamaan dengan kelahirannya atau kehadirannya di dalam kehidupan masyarakat. Artinya, hak-hak yang dimiliki manusia menurut kodratnya yang tidak dapat dipisahkan dari hakikatnya sehingga sifatnya suci. Beberapa hak itu dimiliki tanpa perbedaan atas dasar bangsa, ras, agama, atau jenis kelamin, dan karena itu bersifat universal. Dasar dari semua hak asasi ialah bahwa manusia harus memperoleh kesempatan untuk berkembang sesuai dengan bakat dan cita-citanya.

Persoalan hak asasi manusia ini ternyata bukan persoalan yang mudah, hal ini dibuktikan dengan masih banyaknya persoalan-persoalan pelanggaran hak-hak asasi terutama yang dialami oleh kaum perempuan. Fenomena-fenomena seperti tersebut di atas pada akhirnya menjadi embrio bagi munculnya gerakan feminis di dunia tak terkecuali Indonesia. Namun ironisnya gerakan-gerakan feminis tersebut berkembang menjadi gerakan yang membuat perempuan kehilangan jati diri dan eksistensinya sebagai perempuan yang memiliki kodrat berbeda dengan laki-laki.

Emansipasi wanita, sering dinisbatkan menjadi gerakan tuntutan agar kaum wanita bisa masuk ke bidang-bidang yang diminati sama dengan pria bahkan tak jarang, sampai masuk ke wilayah agama yang sudah jelas dasar dan ketentuannya. Feminisme akhirnya menjadi global theology (agama global). Hal seperti ini tentunya memunculkan banyak kekhawatiran yang mendalam dalam masyarakat Indonesia terutama pemuka agama dan tokoh adat sehingga diperlukan suatu reinterpretasi tentang emansipasi dan nilai-nilai feminisme yang sesuai dengan latar belakang budaya masyarakat Indonesia.

Budaya matrilineal di Sumatera Barat merupakan budaya yang kental dengan nuansa emansipasi dan ajaran feminis. Perempuan me- 
rupakan harta pusaka bagi suatu keluarga sehingga keberadaannya mendapatkan posisi yang sangat terhormat bagi masyarakat. Budaya Minang juga sarat dengan budaya dan ajaran muslim sehingga nilai-nilai kultural religius banyak mempengaruhi pola berpikir masyarakat Minangkabau. Uraian di atas menghasilkan suatu rumusan persoalan sebagai berikut: 1). Bagaimanakah nilai filosofis dari budaya matrilineal di Minangkabau; dan 2). Bagaimanakah relevansi filsafat matrilineal Minang terhadap penegakan hak-hak perempuan di Indonesia. Penelitian ini dilakukan dengan cara membagi budaya Minang ke dalam dua kelompok budaya besar, yaitu Minang Pesisir dan Minang Bukit. Peneliti, setelah itu akan melakukan proses pengumpulan data berkaitan dengan budaya matrilineal di Minangkabau. Pengumpulan data dilakukan dengan cara melakukan wawancara dengan tokoh-tokoh adat dan masyarakat di Sumatera Barat dan dengan observasi langsung ikut terjun dan tinggal beberapa minggu di Minangkabau untuk memahami dan mengetahui secara pasti kehidupan masyarakat Minangkabau terutama perempuan Minang.

Data yang terkumpul kemudian dianalisis dengan menggunakan metode interpretasi dan hermeneutika untuk mendapatkan konsep yang jelas tentang nilai-nilai filosofis dalam budaya matrilineal Minangkabau yang selanjutnya akan dipaparkan dalam suatu seminar di depan tokoh adat dan pemuka masyarakat Minangkabau.

Hasil akhir dari penelitian ini adalah suatu konsep akhir yang selanjutnya dipergunakan menjadi masukan bagi perkembangan gerakan-gerakan perempuan di Indonesia.

\section{SEJARAH MATRILINEAL}

Sejarah matrilineal secara turun-temurun berdasarkan cerita para tokoh di Minangkabau berawal pada masa kepemimpinan Datuk Katumanggungan dan Datuak Parpatiah Nan Sabatang di Minangkabau yang kemudian diserang oleh panglima perang kerajaan Majapahit Adityawarman. Majapahit berniat menyerang daerah minangkabau karena daerah Minangkabau terkenal sebagai daerah yang cinta akan 
perdamaian sehingga tidak memiliki angkatan perang maupun kepolisian.

Karena kerajaan Minangkabau memang kerajaan yang tidak menyukai peperangan dan lebih menyukai cara-cara damai, maka Datuk Katumanggungan berupaya keras mencari cara agar peperangan benar-benar terhindar dan tidak terjadi di bumi Minangkabau. Hingga akhirnya Datuk Katumanggungan bersiasat pada saat panglima Adityawarman sampai di bumi Minangkabau, maka beliau tidak akan disambut dengan pasukan dan peperangan, melainkan disambut dengan keramahtamahan dan akan dipinang untuk dijodohkan dengan adik kandungnya yang bernama putri Jamilah.

Akhirnya sampailah panglima perang Majapahit Adityawarman di ranah Minangkabau. Adityawarman yang datang dari Jawa merasa kaget dengan penyambutan yang dilakukan oleh tentara Minangkabau. Dirinya merasa heran karena Datuk Katumenggungan justru menyambutnya dengan penuh keramahan dan rasa persaudaraan, dan bukannya menyambut dengan bala tentara perang. Utusan dari istana Pagaruyung datang menemuinya dan mengatakan niatnya untuk meminang panglima Adityawarman untuk dinikahkan dengan sang putri dari kerajaan yaitu putri Jamilah yang merupakan adik dari Datuk Katumenggungan. Dan tidak hanya itu demi menghindari perang yang dampaknya akan menyengsarakan rakyat, maka panglima Adityawarman akan diangkat menjadi raja di minangkabau jika bersedia menikah dengan Putri Jamilah. Tentu saja hal itu membuat sang panglima Adityawarman terkejut dan langsung menerima tawaran itu.

Melihat gelagat bahwa panglima Adityawarman akan menerima tawaran itu, maka sang Datuk berusaha mencari cara agar keturunan Putri Jamilah nantinya tetap menjadi orang Minangkabau dan agar semua orang tahu bahwa keturunan Putri Jamilah mendapatkan warisan dari kerajaan Minangkabau dan bukannya mendapatkan warisan dan kekuasaan dari Adityawarman. Maka akhirnya ditetapkanlah adat $B a-$ tali Bacambua yang langsung merubah struktur masyarakat Minangkabau. 
"Nan dikatokan adat nan batali cambua, iyolah hubungan mamak dengan bapak, dalam susunan rumah tango, sarato dalam korong kampuang. Dek Datuak Parpatiah nan Sabatang, didirikan duo kakuasaan, balaku diateh rumah tango, iyolah tungganai jo rajonyo, nan korong kampuang barajo mamak, rumah tango barajo kali,dirumah gadang batungganai. Dicambua tali malakek"

Yang artinya:

"Adat batali bacambua mengatur hubungan antara bapak dan mamak. Intinya, di dalam rumah tangga terdapat dua kekuasaan, pertama kekuasaan bapak, kedua kekuasaan Mamak, yaitu saudara laki-laki dari pihak ibu. Pemikiran itu dibawa Datuk Parpatiah Nan Sabatang pada musyawarah dengan cerdik pandai di balairung sari. Menyadari penting perubahan mufakat didapatkan."

Sejak saat itu susunan aturan masyarakat berubah. Dahulu bapak mewariskan kepada anak sekarang harus kepada kemenakan. Dahulu suku didapat dari bapak, sekarang dari ibu. Ini tidak lebih dari kecerdikan Datuak Parpatiah Nan Sabatang dan Datuk Katumenggungan. Dengan datangnya Adityawarman, ia tetap menginginkan agar kekuasaan tetap berasal dari Datuak Katumanggungan. Dengan waris turun dari mamak, bukan dari bapak ini, nantinya akan memosisikan Adityawarman tidak lebih dari raja transisi bukan raja sebenarnya dari alam Minangkabau. Sebab Datuak Katumanggungan yang menyerahkan kekuasaan padanya, dengan sistem adat yang baru, terkesan hanya menitip kekuasaan. Hingga datang masanya nanti kemenakannya akan lahir dari perkawinan Puteri Jamilah, adiknya dengan Adityawarman.

Cerita tersebut yang secara turun-temurun dipercaya oleh masyarakat minangkabau sebagai cikal bakal dari gerakan matrilineal yang masih dijalani oleh masyarakat Minangkabau hingga sekarang terkait dengan garis keturunan dan warisan yang ditetapkan berdasarkan garis keturunan ibu. Hak perwalian secara adat dari seorang anak bukan terdapat pada ayah kandungnya atau ayah biologisnya, melain- 
kan ada pada paman atau saudara laki-laki ibu yang dalam bahasa Minangkabau disebut mamak.

Perubahan bentuk keluarga luas ke keluarga batih, maka banyak nilai-nilai lain yang berubah. Misalnya pergeseran peran mamak dan ayah. Pada masa sekarang, saudara laki-laki ibu (mamak) tidak lagi mempunyai hak dan kewajiban terhadap anak dari saudara perempuannya (kemenakan). Tanggung jawab terhadap anak sepenuhnya terletak di tangan ayah. Pada masa sekarang, ayah bertindak sebagai "ayah biologis" dan juga "ayah sosial". Pernyataan dalam tulisan Amri Marzali yang mengatakan "bapak adalah ayah biologis dari anakanaknya, sedangkan ayah sosial dari anak-anak tersebut adalah mamaknya" tidak akan ditemukan lagi di lapangan (Marzali, 2000: 10-11). Peneliti menyangsikan etnografi ini merupakan gambaran masyarakat Minangkabau di Silungkang seandainya memang rentang waktu penelitiannya dari tahun 1972 sampai 2000. Gambaran ini hanyalah bentuk yang pernah ada di dalam masyarakat Minangkabau pada masa lalu.

Perkawinan di Minangkabau diatur oleh syarak dan adat. Perkawinan menurut syarak saja (disebut kawin gantuang) dianggap belum selesai. Ada beberapa jenis perkawinan yang dikenal dalam tradisi masyarakat Minangkabau, yaitu:

1. Perkawinan dalam suku/nagari

Ini adalah bentuk perkawinan yang lebih dianjurkan di Minangkabau. Namun yang ideal lagi adalah perkawinan antarkeluarga terdekat, seperti: menikahi anak mamak (pulang ka mamak) atau menikahi kamanakan bapak (pulang kabako).

2. Perkawinan luar suku

Ini berarti menikah dengan orang non-Minangkabau. Perkawinan dengan perempuan dari luar suku Minangkabau tidak disukai karena bisa merusak struktur adat. Si anak tidak akan mempunyai suku. Sebaliknya, perkawinan dengan laki-laki luar suku Minangkabau tidak dipermasalahkan, karena tidak merusak struktur adat dan anak tetap mempunyai suku dari ibunya. 
3. Perkawinan terlarang (perkawinan pantang)

a. Perkawinan yang dilarang sesuai syariat Islam, seperti menikahi ibu, ayah, saudara, anak saudara seibu dan sebapak, dan lainlain.

b. Perkawinan yang merusak sistem adat, yakni menikahi orang yang setali darah menurut garis ibu, orang sekaum, atau orang sesuku.

c. Perkawinan yang dilarang untuk memelihara kerukunan sosial, seperti menikahi orang yang diceraikan kerabat, memadu perempuan yang sekerabat, menikahi anak tiri saudara kandung, atau menikahi orang yang dalam pertunangan.

Orang yang tetap melakukan perkawinan terlarang ini akan diberi sanksi, misalnya membubarkan perkawinan itu, diusir dari kampung, atau hukum denda dengan meminta maaf pada semua pihak pada suatu perjamuan dengan memotong seekor atau dua ekor ternak.

Menurut hasil wawancara dengan narasumber peneliti yang bernama Hj. Ermalis kekerabatan di Minangkabau terdiri dari dua bentuk yaitu:

1. Kekerabatan dalam suku, terjadi karena sistem matrilineal yang dianut orang Minangkabau. Contoh: ibu - anak, mamak - kamanakan, dan sebagainya.

2. Kekerabatan luar suku, terjadi karena adanya perkawinan. Contoh : sumando - pasumandan, minantu - mintuo, induak bakoanak pisang, dan sebagainya.

Masyarakat Minangkabau menganut sistem kekerabatan matrilineal, yakni kekerabatan yang menarik garis keturunan menurut garis ibu. Jadi suku seseorang di Minangkabau mengikuti suku ibunya. Seorang perempuan memiliki kedudukan istimewa di dalam kaum. Orang sesuku tidak boleh menikah. Yang menguasai harta pusaka adalah ibu dan yang mengikat tali kekeluargaan rumah gadang adalah hubungan dengan harta pusaka dan sako (gelar). Wanita tertua di kaum dijuluki limpapeh atau amban puruak. Ia mendapat kehormatan sebagai 
penguasa seluruh harta kaum. Pembagian harta diatur olehnya. Sedangkan laki-laki tertua di kaum dijuluki tungganai. Ia bertugas sebagai mamak kapalo warih. Ia hanya berkuasa untuk memelihara, mengolah, dan mengembangkan harta milik kaum, tapi tidak untuk menggunakannya.

Orang-orang akademis memberi suatu istilah untuk mengkaji sistem masyarakat di minangkabau yang bergariskan keturunan ibu yaitu matrilineal agar untuk mempermudah pemaknaannya. Matrilineal berasal dari kata "matri" artinya (ibu) dan "lineal" (garis), sehingga berarti "garis ibu". Maksudnya yaitu istilah untuk menyebutkan sistem kekerabatan yang mengacu pada garis keturunan ibu. Di Minangkabau sistem kekerabatan tentunya merupakan penjabaran ajaran syarak Hablumminanas, dan merupakan formulasi untuk menyikapi fitrah Allah Swt yang menjadikan manusia berkelompok-kelompok dan berbangsa-bangsa.

Penyempurnan penyikapan atas fitrah dan sekaligus implementasi dari ajaran syarak, maka selain hubungan-hubungan yang wajib dijaga menurut ajaran Islam, maka nenek moyang orang Minangkabau menyempurnakan kekerabatan dengan merefleksikan hubungan menurut garis keturunan ibu sebagai berikut:// Hubungan antara Ibu dan Anak// Bapak dan Anak// Hubungan kekerabatan Mamak jo Kamanakan// Hubungan kekerabatan Suku jo Sako// Hubungan kekerabatan Induak Bako jo Anak Pisang// Hubungan kekerabatan Andan Pasumandan//, dan lain-lain. Hukum waris di dalam Islam telah diterapkan dalam Adat Minangkabau, bahkan hukum waris secara Islam ini yang menjadi roh sesungguhnya dalam merumuskan sistem harta kekayaan, seperti ketentuan: Jan kan sawah jo ladang, rimbo jo rumah gadang, nan dirikito sandiribukanlah kito nan punyo.

Inilah ajaran dasar dari setiap persoalan harta dan kekayaan di Alam Minangkabau. Dalam pemahaman adat Minangkabau amanah adalah tanggung jawab yang amat berat, seluruh rahmat dan karunia wajib dipertanggungjawabkan baik di dunia dan akhirat. Harta dan warisan dalam ajaran adat Alam Minangkabau tidak mengenal adanya hak milik karena yang berhak memiliki hanyalah Allah Swt.. Adat Mi- 
nangkabau telah merumuskan. Hak Peruntukan pada perempuan sedangkan Hak Pengelolaan (kepemimpinan) pada para lelaki. Jadi dari segi sistem adat tidak melanggar yang dikatakan oleh syarak. Begitu juga dengan aturan yang berdasarkan menurut Nasab Ayah (Istilah Dunsanak).

Islam tidak mengusik ketentuan adat. Pusaka Tinggi dan Pusaka Rendah adalah suatu kearifan tersendiri bagi Adat Minangkabau. Harta Pusaka Rendah adalah harta pencarian, semua diatur sepenuhnya menurut ketentuan Syarak. Dalam pengelompokan hukum adat harta pusaka tinggi sampai saat ini masih menjadi perdebatan, karena mereka beranggapan bahwa harta pusaka tinggi tidak ada di dalam aturan Islam atau penempatanya tidak sesuai dengan ajaran syarak. Orang Minangkabau telah mengakui harta pusaka tinggi adalah harta yang tidak bertuan, atau tidak jelas asal usulnya, sehingga harta pusaka tinggi diwariskan melalui garis keturunan ibu sebagai umbun puruk pagangan kunci. Seandainya harta ini diwariskan kepada kaum laki-laki pasti akan mengalami dampak kekacauan, sewaktu kecil dia tinggal bersama orang tuanya setelah menikah harta ini dibagi dan dibawa kepada keluarganya maka kesejahteraan kepada semua unsur mengalami kekacauan.

Pandangan dari sekularisme, atau kacamata materialisme dan kapitalisme yang jahiliyah, telah menghancurkan pandangan mendasar dalam beradat di Minangkabau, yaitu sistem adat dan syarak yang tertata rapih yang disusun secara hati nurani. Pemikiran sekularisme yang mulai nenjajah Minangkabau memberikan kebimbangan untuk menafsirkan adat yang sempurna ini, kalau seandainya masyarakat berbudaya masih memaknai Adaik Basandi Syarak, Syarak Basandi Kitabullah yang bisa digunakan untuk memahami karakter umum penjajah baik fisik atau nonfisik yang bisa juga disebut sebagai ideologi penjajah. Sudah pasti Adat dilindungi dengan tuah kato dari syarak yang bersandi kepada Al-Qur'an. (Accarja, 2006)

Sistem sosial matrilineal di Minangkabau dibentuk berdasarkan kepada ketentuan-ketentuan alam yang kodrati. Secara alamiah yang 
mengandung, melahirkan, menyusukan, mengajarkan anak berkatakata dan mendidiknya adalah seorang ibu. Sedangkan ayah sedikit sekali mendapat kesempatan untuk bergaul dengan anak-anak dan memperhatikan kebutuhan-kebutuhannya. Seorang ayah lebih banyak berada di luar rumah karena harus mencari nafkah untuk memenuhi kebutuhan istri dan anaknya. Konsekuensinya yang tidak jarang terjadi adalah anak-anak lebih dekat dan merasa nyaman ketika berada di samping ibunya. Kondisi-kondisi alamiah seperti inilah yang dijadikan sebagai sumber dalam menetapkan suatu sistem sosial di Minangkabau.

Sistem sosial yang ditetapkan berdasarkan kondisi kondisi objektif alamiah tersebut menyebabkan sistem ini menjadi sistem yang universal dan sangat kuat mengakar dalam masyarakat Minangkabau. Sehingga betapapun derasnya arus perubahan yang dibawa merongrong kekokohan posisinya, dia tetap tegar. Misalnya arus perubahan yang dibawa oleh, arus modernisasi ataupun arus merantau. Faktor-faktor tersebut tidak mampu menggeser kedudukan ini, bahkan yang terjadi malah sebaliknya, faktor-faktor ini membuat posisinya semakin kuat. Berdasarkan realitas tersebut, oleh karenanya kekawatiran akan melemahnya sistem matrilineal dan akan bergeser oleh sistem patrilineal tidak perlu menjadi suatu ketakutan yang berkepanjangan sebab sistem ini akan tetap dianut oleh masyarakat Minangkabau, selama masih ada kaum ibu yang mempertahankan citranya dan kodratnya sebagai wanita. Meskipun banyak faktor-faktor yang bertentangan, seperti faktor agama Islam yang mencoba mempertentangkan dengan sistem patrilineal, tapi faktor ini tidak mampu menggoyahkan eksistensi ini. Sampai sekarang masyarakat Minangkabau masih menganut agama Islam, akan tetapi dalam hal ini terjadi proses akomodasi yang seimbang. Pada satu pihak orang Minangkabau harus menjalankan esensi ajaran Islam yang murni dan pada pihak yang lain mereka tetap mempertahankan keaslian adat dan sistemnya. Proses akomodasi yang tidak merugikan salah satu pihak ini ditambah oleh suatu produk kata Tsuyushi Kato dalam tesisnya yang berjudul "Matriliny and Migration Evolving Minangkabau Tradition in Indonesia" tahun 1982. 


\section{FEMINISME DALAM BUDAYA MATRILINEAL DI MINANGKABAU}

Perempuan dan laki-laki berbeda secara badaniah. Hal tersebut mengakibatkan perempuan dan laki-laki mempunyai fungsi yang berbeda dalam kehidupan bermasyarakat, baik secara domestik maupun secara publik. Pembagian kerja seperti ini sudah berlangsung selama ribuan tahun sehingga masyarakat cenderung menganggapnya sebagai sesuatu yang alamiah. Banyak yang tidak bertanya lagi apakah pembagian kerja seperti ini adil, dan siapa yang diuntungkan dalam pembagian kerja seperti ini. Kaum perempuan sendiri bahkan juga cenderung beranggapan bahwa perbedaan peran yang diberikan kepada perempuan dan laki-laki sama nilainya.

Perdebatan tentang perbedaan psikologis antara laki-laki dan perempuan pada dasarnya berputar di sekitar dua teori besar yaitu teori nature yang beranggapan bahwa perbedaan psikologis antara laki-laki dan perempuan disebabkan oleh faktor-faktor biologis, dan yang kedua adalah teori nurture yang beranggapan bahwa perbedaan tersebut tercipta oleh lingkungan.

Dari pelbagai gugatan terhadap ketidakadilan tersebut, terdapat suatu analisis akan perbedaan yang mempertanyakan ketidakadilan sosial dari aspek hubungan antarjenis kelamin. Perbedaan-perbedaan tersebut yang pada akhirnya mencetuskan berbagai macam polemik dalam masyarakat yang kita kenal dengan istilah perbedaan gender.

Keadaan seperti ini, perempuan jadi tergantung kepada laki-laki secara ekonomis, karena pekerjaan yang dilakukan di rumah tangga tidak menghasilkan gaji. Ditambah lagi, perempuan seakan-akan dipenjarakan di suatu dunia yang tidak merangsang perkembangan kepribadiannya. Mereka mengerjakan pekerjaan yang monoton setiap hari, diulang jutaan kali. Teman-temannya terbatas, dan hidupnya kebanyakan dilewati bersama anak-anaknya.

Betty Friedan, seorang tokoh gerakan feminis Amerika secara dramatis melukiskan keadaan ini sebagai berikut:

Seorang perempuan akan berkata : "Saya merasa kosong, merasa tidak lengkap"...kadang-kadang (si perempuan 
melanjutkan) dia mengeluh kepada seorang dokter tentang gejala-gejala perasaan yang tidak bisa digambarkan dengan baik. "Saya merasa lelah, saya ingin cepat marah kepada anak-anak saya, dan ini membuat saya khawatir...saya mau menangis tanpa tahu apa sebabnya..." (Friedan, 1974:20).

Pada masa sekarang ini ada kenyataan bahwa tidak semua perempuan bahagia hidup dalam lingkungan rumah tangga. Ini berarti hidup dalam lingkungan rumah tangga bagi perempuan belum tentu merupakan kodrat alamiah perempuan. Sebab jika tidak, tentu perempuan akan berbahagia menunaikan tugas yang diberikan oleh kodrat mereka.

Apabila seorang perempuan tidak dikodratkan sebagai "perempuan" dalam bentuk yang sudah dikenal umat manusia sampai saat ini, maka juga harus diragukan apakah sifat-sifat perempuan yang lebih emosional atau lebih pasif atau lebih submisif merupakan sesuatu yang lebih alamiah juga? Keraguan itu timbul belum begitu lama dalam sejarah umat manusia. Salah satu buku yang terkenal yang membicarakan keraguan ini ditulis oleh ahli filsafat Inggris John Stuard Mill pada tahun 1869. Dalam esay yang berjudul The Subjection Of Woman, Mill berkata bahwa apa yang disebut sebagai sifat keperempuanan adalah hasil pemupukan masyarakat melalui suatu sistem pendidikan. Mill percaya bahwa usaha-usaha untuk membagi manusia menjadi dua golongan, laki-laki dan perempuan, dan usaha untuk membedakan kedua golongan manusia ini dalam peranan sosial mereka, merupakan suatu tindakan politik yang direncanakan. Golongan yang lebih kuat, yakni kaum laki-laki, selalu melihat keunggulannya sebagai sesuatu yang alamiah.

Perbedaan gender seharusnya tidaklah menjadi masalah sepanjang tidak menghasilkan ketidakadilan gender (gender inequalities). Namun yang menjadi persoalan, ternyata perbedaan gender telah melahirkan berbagai ketidakadilan, baik bagi kaum laki-laki dan terutama bagikaum perempuan.

Fakta kehidupan dalam masyarakat yang terkait dengan sistem patriarkhi memiliki akar sejarah yang panjang, berawal dari sikap 
dominasi laki-laki atas perempuan, dalam mayoritas sektor yang dibangun atas dasar tatanan yang timpang, yakni tatanan nilai yang menempatkan laki-laki pada pihak yang dianggap kuat (superior), di hadapan perempuan yang dianggap lemah (inferior). Sekalipun tatanan yang timpang ini sudah mapan kokoh selama berabad-abad, dan berlaku begitu alamiah bahkan oleh perempuan sendiri, tidaklah menjadi alasan untuk dipertahankan, atau menjadi pesimis untuk mengkaji ulang akan kebenarannya, demi menciptakan tatanan yang lebih religius dan humanis.

Budaya patriarkhi sangat mewarnai mayoritas bidang kehidupan, dan pada gilirannya mengurangi otonomi perempuan. Keadaan ini terbukti telah melahirkan suatu proses marjinalisasi, bahkan eksploitasi dan kekerasan terhadap perempuan yang terjadi dalam segala ruang, baik domestik maupun publik.

Dalam masyarakat masa kini seperti halnya masyarakat Indonesia, kehidupan perempuan berputar di seputar kehidupan rumah tangga. Dalam keadaan seperti ini perempuan menjadi sangat bergantung kepada laki-laki secara ekonomis. Hal tersebut yang terkadang mengakibatkan kedudukan perempuan "lebih lemah" di banding dengan laki-laki dalam lingkungan keluarga. Dan hal inilah yang menjadi embrio bagi lahirnya berbagai macam gerakan feminisme di Indonesia tak terkecuali di Minangkabau Sumatera Barat.

Feminisme di Indonesia, masih "barang baru" (produk Barat). Dalam pengantar terjemahan buku "Feminist Thought", Aquarini Priyatna Prasmoro, seorang akademisi yang intens dengan pemikiran feminis di Indonesia, mengungkapkan kegelisahan yang menganggu pikirannya terkait tuduhan bahwa feminisme adalah Barat. "Pemikiran feminisme radikal seringkali dianggap tidak sesuai dengan 'budaya Timur', karena perbincangan seksualitas bagi pemikiran Timur adalah tabu". Menurut Aquarini, "adalah asumsi merendahkan bahwa perempuan Timur tidak mampu melihat ketimpangan yang muncul secara jelas di depan mata." (Tong, 1998; hal xv).

Minangkabau, sebuah daerah di pulau Sumatera, yang sekarang identik dengan wilayah Sumatera Barat, memiliki kultur budaya yang 
unik dalam mengatur kehidupan masyarakatnya. Minangkabau adalah salah satu masyarakat yang masih tetap memegang matrilineal (sistem kekerabatan menurut garis ibu). Para Antropolog mencatat saat ini, suku bangsa yang masih memegang sistem matrilineal, kurang dari 10 suku bangsa, di antaranya, Minangkabau (Sumatera Barat, Indonesia), Campa (Vietnam), Muangthai (segitiga emas Thailand), suku bangsa di India, Afrika, dan Badui (Timur Tengah).

Adat Minangkabau bersifat matrilineal. Dalam menentukan tempat tinggal suami-istri, adat Minangkabau menganut sistem matrilokal. Dalam adat Minangkabau, yang berkuasa dan bertanggung jawab dalam sebuah rumah tangga adalah ibu yang didampingi oleh mamak (saudara laki-laki ibu), sedangkan ayah hanya sebagai tamu. Dalam perkawinan, menurut adat Minangkabau yang meminang bukan laki-laki atau keluarganya, akan tetapi pihak perempuan. Dalam pembagian harta warisan kaum/suku jatuh pada kepada perempuan, sementara kaum laki-laki tidak mendapatkan bagian apa-apa. Perempuan menempati kedudukan yang istimewa (Ilyas, 2006: 47-49). Garis keturunan menurut ibu, menimbulkan kecenderungan negatif bagi laki-laki di Minangkabau. Mereka dianggap hanyalah sebagai "pejantan", yang dinikahi oleh perempuan untuk menjaga eksistensi suku sang perempuan. Tapi sisi lain, matrilineal telah memberikan status yang jelas bagi seorang anak, bahwa ia adalah anak dari ibunya. Sebagaimana telah diketahui dalam masalah seksual, patrilineal telah menempatkan perempuan pada posisi yang rendah (belum lagi penderitaan dan sakit karena hamil).

Dalam Diskusi "Memahami Sistem Matrilineal Minangkabau", 25 Desember 2007 di Yogyakarta, Dr. Raudha Thaib (Budayawan Sumatera Barat) mengatakan, “Di Minangkabau, perempuan diperbolehkan untuk memasuki wilayah publik. Perempuan Minang tidak dikurung di rumah dan hanya berkecimpung di sektor domestik saja. Perempuan memegang peranan dalam pengambilan keputusan politik dalam kaum/suku dan diperbolehkan untuk menduduki jabatan publik. Dalam sejarah, Kerajaan Minangkabau pernah dipimpin oleh raja Perempuan, yang bernama "Bundo Kanduang". Hanya tiga posisi 
yang tidak boleh ditempati perempuan, yaitu Manti (pemimpin adat), Malin (pemimpin agama), dan Dubalang (pemimpin keamanan suku). Selain dari tiga posisi ini, perempuan dipersilahkan untuk berkiprah dan mendudukinya." (Diskusi Gebu Minang di Asrama Mahasiswa Bundo Kanduang Yogyakarta).

Perempuan di Minangkabau telah mendapat legitimasi yang kuat dalam hal mendapatkan hak kepemilikan pribadi dan kebebasan berkiprah di dunia politik. Perempuan Minang oleh adat diberikan hak properti, seperti memiliki sawah, rumah, ladang, dan tanah. Dalam keluarga mereka sulit diintimidasi oleh suami, karena mamak (saudara laki-laki dari sukunya) akan senantiasa memberikan perlindungan kepada perempuan tersebut, sehingga sangat kecil kemungkinan suami bisa sewenang-wenang (melakukan kekerasan) terhadap istri. Jika perempuan harus keluar untuk memasuki industri publik, maka untuk konteks matrilineal Minangkabau ini tidak diperlukan lagi karena perempuan telah memiliki properti yang bisa ia sewakan atau dikelola, sehingga properti tersebut semakin bertambah (paling tidak tetap jumlahnya seperti semula). Perempuan Minang tidak mesti harus mengolah sendiri, tapi cukup menjadi manajer dari pengelolaan pertambahan aset yang dimiliki. Biasanya yang difungsikan sebagai pekerja untuk menambah aset tersebut adalah suami, yang "dijemput" oleh pihak/ keluarga perempuan. Pengalaman sebagai manajer ini, bisa membentuk karakter kepimpinan yang pada level lebih tinggi bisa dia gunakan dalam wilayah kepemimpinan politika.

Ketika adat Minangkabau, telah menempatkan posisi perempuan lebih penting dari laki-laki, apakah bisa dikatakan feminisme tidak berlaku untuk masyarakat Minangkabau? Mungkin, banyak yang akan mengatakan tidak perlu. Namun, menurut hemat peneliti, feminisme sebagai sebuah spirit dan gerakan penyadaran akan posisi perempuan yang subordinat dari laki-laki, masih dibutuhkan oleh perempuan Minang. Ada beberapa kondisi yang menguatkan pendapatini, yaitu:

1. Perempuan Minang, karena telah diberikan perlakuan istimewa oleh adat, cenderung untuk bermalas-malasan, tidak memiliki sebu- 
ah visi menatap masa depan, kecuali keinginan untuk mendapatkan suami kaya dan berpangkat sehingga semakin membuat dirinya 'larut' dalam "kebahagiaan materi",

2. Seperti kategorisasi Engels bahwa ada perempuan borjuis dan proletar, maka di Minang ada juga kelas perempuan miskin (karena sukunya miskin), yang tidak memungkinkan ia untuk memperoleh hakhak properti dan kedudukan politis istimewa di masyarakat. Bagi mereka ini, pemikiran feminisme masih diperlukan untuk meningkatkan harkat dan martabatnya,

3. Karena "dininabobokkan" oleh hak istimewa, banyak perempuan yang merasa cukup dengan hak istimewa itu. Kenyataan ini membuat mereka nyaman berperan hanya di wilayah domestik (rumah tangga) saja, sehingga jarang yang mau berkiprah di wilayah publik. Hal ini dapat dilihat pada minimnya perempuan Minang berkiprah dibidang politik maupun perusahaan.

Amri Marzali memaparkan bahwa bentuk keluarga luas adalah bentuk keluarga masyarakat Minangkabau (Marzali, 2000: 10-11). Dengan berubahnya bentuk keluarga luas ke keluarga batih, maka banyak nilai-nilai lain yang berubah. Misalnya pergeseran peran mamak dan ayah. Pada masa sekarang, saudara laki-laki ibu (mamak) tidak lagi mempunyai hak dan kewajiban terhadap anak dari saudara perempuannya (kemenakan). Tanggung jawab terhadap anak sepenuhnya terletak di tangan ayah. Pada masa sekarang, ayah bertindak sebagai "ayah biologis" dan juga "ayah sosial". Amri Marzali mengatakan "bapak adalah ayah biologis dari anak-anaknya, sedangkan ayah sosial dari anak-anak tersebut adalah mamaknya" (Marzali, 2000: 10-11). Jika kita mengamati pola kehidupan masyarakat minangkabau sekarang, hal seperti itu sudah tidak berlaku lagi.

Amri Marzali juga mengatakan bahwa sebagian besar prinsip kultural matrilineal sudah tidak dijalankan lagi dalam kehidupan sosial masyarakat Minangkabau di Jakarta. Pernyataan ini dikeluarkan pada tahun 2000 dalam jurnal Antropologi Indonesia Th. XXIV, No. 61 edisi Januari-April 2000.

Satu bukti yang mengagetkan lagi adalah pernyataan dari 
Mohammad Hatta, salah satu proklamator kemerdekaan Indonesia, dalam memoirnya. Hatta menuliskan bahwa dalam keluarganya pada masa kecilnya di Bukittinggi sudah tidak melaksanakan lagi bentuk keluarga luas ini. Hatta tinggal bersama ibu, ayahnya dan saudara-saudaranya. Hatta lahir pada tahun 1908. Jadi, kira-kira pada tahun 1900an sampai 1915-an perubahan sosial terhadap bentuk keluarga luas ini sudah dimulai pada daerah asalnya, dalam hal ini di Bukittinggi. Namun, Hatta juga menuliskan bahwa di kampung-kampung di sekitar kota tempat ia lahir masih melaksanakan bentuk keluarga luas ini.

\section{NILAI-NILAI DALAM MATRILINEAL DAN PENGARUHNYA BAGI PENEGAKAN HAK-HAK PEREMPUAN DI INDONESIA}

Istilah hak asasi manusia merupakan terjemahan dari droits de l'homme (Perancis), human rights (Inggris), dan menselijke rechten (Belanda). Di Indonesia hak asasi pada umumnya lebih dikenal dengan istilah "hak-hak asasi" sebagai terjemahan dari basic rights (Inggris) dan grondrechten (Belanda), atau bisa juga disebut hak-hak fundamental (civil rights). Istilah hak-hak asasi secara monumental lahir sejak keberhasilan Revolusi Perancis tahun 1789 dalam "Declaration des Droits de L'homme et du Citoyen" (hak-hak asasi manusia dan warga negara Perancis), dengan semboyan Liberte, Egalite, Fraternite. Namun demikian, sebenarnya masalah hak-hak asasi manusia telah lama diperjuangkan manusia di permukaan bumi.

Latar belakang sejarah hak asasi pada hakekatnya muncul karena keinsyafan manusia terhadap harga diri, harkat, dan martabat kemanusiaannya sebagai akibat dari tindakan sewenang-wenang dari penguasa, penjajahan, perbudakan, ketidakadilan, dan tirani yang melanda seluruh umat manusia. Dalam proses ini telah lahir beberapa naskah yang secara berangsur-angsur menetapkan bahwa ada beberapa hak yang mendasari kehidupan manusia dan karena itu bersifat universal. Naskah-naskah itu, beberapa di antaranya adalah Magna Charta (1215), Bill of Rights (1689), Declaration of Independence (1776), Declaration des Droits de L'homme et du Citoyen (1789), Atlantic Charter (1941), dan Universal Declaration of Human Rights (1948). Bahkan bebe- 
rapa pemikir Islam melihat bahwa Piagam Madinah dapat dikategorikan sebagai deklarasi hak asasi manusia pertama di dunia. Dalam piagam tersebut, setiap masyarakat Madinah diperbolehkan menganut agama masing-masing dan tidak mengganggu orang untuk beribadah. Karena itu para pemikir Islam banyak yang beranggapan bahwa piagam ini merupakan teks pengakuan hak asasi manusia. Walaupun teks ini dilanggar oleh kelompok non Muslim, namun sumbangsih Islam terhadap cetak biru hak asasi manusia di bumi ini haruslah diakui (Jeri Inderawan, tanpa tahun).

Pemikiran tentang hak asasi manusia mendapat landasan yang kuat seusai berakhirnya Perang Dunia II, setelah dunia mengalami salah satu bentuk kekuasaan yang paling mengerikan dalam sejarahnya, yakni fasisme. Pada saat bersamaan, di berbagai belahan tanah jajahan muncul negara-negara baru yang merdeka, termasuk Indonesia. Semangat yang hadir saat itu adalah keadilan, kebebasan, dan penolakan terhadap segala jenis penindasan.

Naskah Pembukaan UUD NRI 1945 mencatat semangat tersebut dengan mengatakan "kemerdekaan adalah hak segala bangsa dan oleh sebab itu maka penjajahan di atas dunia harus dihapuskan". Semangat yang sama juga tercermin dalam perumusan Deklarasi Umum Hak Asasi Manusia. Seperti yang sudah disebutkan, dalam Batang Tubuh UUD 1945 (sebelum diamandemen) juga dapat ditemukan pasal-pasal tentang hak asasi manusia yaitu Pasal 27-31.

Perkembangan selanjutnya di Indonesia, perlindungan atas hak asasi manusia dirasa masih kurang. Pada Sidang Konstituante tahun 1950 perubahan pun dilakukan dengan mencantumkan 28 pasal khusus tentang hak asasi manusia. Dimasukkannya pasal-pasal baru yang mengatur tentang hak asasi manusia ini berlangsung dalam proses pembentukan sistem kenegaraan yang lebih terbuka dan pastinya demokratis, serta menciptakan tatanan ekonomi, sosial, dan budaya yang adil.

Proses ini kemudian dipatahkan pada tahun 1965. Perubahan politik menyusul usaha kudeta yang gagal tersebut membuat terjadinya kekerasan yang tidak ada bandingnya dalam sejarah negeri ini. Di hampir seluruh wilayah Indonesia terjadi pembunuhan, penyiksaan, 
perkosaan, penangkapan, dan penahanan sewenang-wenang, pengadilan tidak adil terhadap sebagian anggota dan simpatisan Partai Komunis Indonesia (PKI) serta pendukung Soekarno.

Pengakuan dan penghargaan terhadap hak asasi manusia dikesampingkan dengan alasan "menjaga keselamatan bangsa", dan pembicaraan tentang hak asasi manusia sebagai ketentuan konstitusional pun terkubur. Dekrit Presiden tahun 1959 dipandang sebagai momentum terhentinya pembicaraan tentang hak asasi manusia, dengan dibubarkannya Konstituante dan kembali berlakunya UUD 1945.

Hak asasi manusia juga mencuat manakala sekelompok perempuan mulai menggelorakan tutntutan hak persamaan atas kaum lakilaki. Feminisme atau paham kesetaraan gender semakin deras pengaruhnya, setelah digelarnya Konferensi PBB IV tentang perempuan di Beijing tahun 1995. Di Indonesia, hasil konferensi tersebut dilaksanakan oleh para feminis, baik melalui lembaga pemerintah, seperti tim Pengarusutamaan Gender Depag, Departemen Pemberdayaan Perempuan, maupun melalui LSM-LSM yang kian menjamur. Di ranah pendidikan tinggi, telah didirikan institusi-institusi Pusat Studi Wanita (PSW/PSG). Kementerian Negara Pemberdayaan Perempuan, dalam www.mennegpp.go.id, melaporkan, jumlah PSW hingga tahun 2005 telah mencapai 132 di seluruh universitas di Indonesia.

Persoalan perempuan yang termarginalkan juga menjadi persoalan baru di negeri ini. Sudah dari dulu, adanya pertentangan kelas menjadi masalah untuk gerakan emansipasi perempuan. Di Inggris misalnya, gerakan feminis terpecah setelah Perang Dunia I. Sayap kiri yang dipimpin oleh Sylvia Pankhurst menjadi sosialis dan memperjuangkan hak-hak buruh perempuan di bilangan miskin kota London. Sedangkan ibunya Emmeline Pankhurst dan kakaknya Christobel Pankhurst memusatkan perhatian mereka kepada kepentingan golongan tengah dan menjadi orang sayap kanan.

Demikian pula, gerakan Women's Liberation tahun 1970-an di Barat telah terpecah-pecah. Sebagian menjadi sosialis dan/atau tetap radikal, sedangkan sebagian lainnya mancapai karir yang gemilang dan tidak menghiraukan lagi nasib perempuan rakyat kecil. Untuk me- 
ngerti asal-muasal perkembangan ini, perlu dianalisis penindasan perempuan dengan lebih mendalam.

Sistem kapitalis membutuhkan dua macam sumber daya. Dari satu sisi membutuhkan modal, seperti pabrik-pabrik, dan kantor-kantor, bank-bank. Dari sisi lainnya memerlukan tenaga kerja yang sehat dan trampil - dan ini mahal. Aparatus negara menyediakan beberapa pelayanan yang penting seperti sekolah-sekolah, rumah-rumah sakit, dan sebagainya. Namun sebagian besar dari waktu, upaya dan uang yang diperlukan untuk mereproduksi tenaga kerja baru disediakan oleh keluarga masing-masing. Inilah kunci pokok untuk mengerti penindasan yang dialami kaum perempuan. Sistem kapitalis mengandalkan pekerjaan tanpa upah yang dilakukan kaum ibu di dalam keluarga, untuk menghasilkan tenaga kerja baru. Segala unsur lain dari penindasan perempuan -- diskriminasi di tempat kerja, stereotip seksual, bahkan pelecehan dan pemerkosaan - berkaitan dengan dan memperkuat peranan rumah tangga ini.

Feminisme akhirnya menjadi global theology (agama global) dan semakin mengakar pengaruhnya di Indonesia, setelah masuk dalam 10 program PKK dan diresmikannya UU Pemilu 2003 Pasal 65 Ayat 1 yang menyatakan batas minimal keterwakilan perempuan sebagai anggota DPR/DPRD dari setiap partai adalah 30\%. (Ninuk Mardiana, Kompas, 16/4/07). Namun dalam perkembangannya, gerakan feminisme telah menyimpang dan mencampuri ranah studi Islam. Bahkan kampanye menuntut keadilan dan peran sosial yang lebih luas bagi wanita seringkali mengabaikan ajaran agama.

Alih-alih berharap memperjuangkan kesetaraan gender, para pengkiblat Barat ini juga menuntut 'kesetaraan' hak waris, hak menjadi imam shalat dan hak azan, hak penyamaan batasan aurat dan pakaian ihram, aqiqah, kesaksian, air kencing bayi, kepemimpinan dalam negara dan rumah tangga, isu-isu perkawinan, termasuk masalah kewalian, mahar, hak talak, masa 'iddah, dan poligami. Bahkan yang mengejutkan, atas nama 'kesetaraan' gender pula, mereka menuntut hal-hal yang jelas dilarang oleh Al-Quran. Di antaranya menuntut dibolehkan menikah dengan lelaki non-muslim, dibolehkan memilih pasangan 
lesbian (hubungan sejenis antara wanita dengan wanita, sebagai hal yang pernah diperangi di zaman Nabi Luth).

Pada intinya, feminisme dalam batasan tertentu adalah 'teologi kemarahan'. Gugatan feminisme sebenarnya berawal dari kerancuan pandangan Barat dalam memaknai keadilan, rasional, dan HAM. Dalam The New Oxford Dictionary of English dijelaskan bahwa tindakan yang adil berarti kualitas yang adil dan rasional (the quality of being fair and reasonable). Sedangkan rasional di kamus ini diartikan sebagai tindakan atau pertimbangan yang dasarnya sejalan dengan akal atau logika. Namun anehnya, penggunaan contoh kata rasional dalam kalimat, ternyata sikap rasional selalu dinisbahkan pada kaum laki-laki. She's not being very rational; Man is a rational being. Dalam masyarakat Barat terjadi perdebatan sengit yang menuntut penafsiran ulang terhadap Alkitab yang dipandang penyebab utama dalam merendahkan wanita.

Persoalan feminisme dalam budaya matrilineal adat Minangkabau di Sumatera Barat pada hakikatnya merupakan budaya yang menjadi cikal bakal bagi gerakan feminisme di Indonesia. Budaya matrilineal di Minangkabau menempatkan posisi perempuan sebagai posisi yang menentukan kehidupan masyarakat dan keberlangsungan keturunannya. Namun hal tersebut tidaklah menjadi suatu hal yang begitu saja menguntungkan bagi masyarakat Minangkabau. Posisi dan kedudukan perempuan beserta keluarganya yang sangat dominan tersebut yang terkadang menjadikan posisi laki-laki justru sebagai posisi yang terjepit dan tidak mendapatkan penghargaan.

Kedudukan dan posisi perempuan yang kuat, terutama berkaitan dengan persoalan warisan menjadikan posisi perempuan memiliki kedudukan yang kuat dalam lingkungan sosial kemasyarakatan dikarenakan perempuan yang dianggap memiliki harta dalam keluarga. Kekuatan materi tersebut yang menjadikan perempuan di Minangkabau memiliki kepercayaan diri untuk bisa menduduki posisi yang penting di ranah publik. Kedudukan perempuan sebagai kekuatan adat yang memiliki hak pewarisan yang berbeda dengan laki-laki juga menjadikan perempuan Minangkabau memiliki kekuatan materi apabila mendapati suaminya berpoligami 
Adat Minangkabau sangat kokoh menetapkan laki-laki yang sebagai seorang pemimpin bagi nanak, kamanakan, istri, dan lingkungan sosial secara luas, Syarak manyatatakan falsafah adat ini di dalam Al-Qur'an (QS An-Nisa ayat 34). Adat di Minangkabau tidak melanggar hukum syarak, aplikasi ini bisa ditemui ketika pengangkatan penghulu, salah satu syarat manjadi pangulu adalah Laki-laki nan Baligh jo Baraka Lalu sifat pangulu adolah sifat Rasulullah SAW (Siddik, Amanah, Tabliq, Fathonah). Dalam membahas adat jo syarak tidak perlu diperdebatkan. Terkecuali adat jo syarak kok bacarai, inilah yang perlu dikokohkan sebab adaik dan syarak sandar menyadar, keduanya tidak bisa dipisahkan. Perdebatan bukanlah sifat orang Minang sebab perdebatan akan mengundang perpecahan.

Kekuatan posisi perempuan dalam budaya matrilineal dan posisi laki-laki yang juga sangat berpengaruh dalam kebudayaan Minangkabau menjadikan perempuan Minangkabau memiliki hak-hak yang proporsional berdasarkan kedudukannya sebagai bagian dari umat manusia. Posisi perempuan menjadi posisi yang kuat karena memiliki nilai tawar yang tinggi, sedangkan posisi perempuan juga bukan merupakan posisi yang mutlak yang bisa mengalahkan kedudukan lakilaki dalam lingkungan dan pergaulan sosial.

Kondisi seperti ini dirasa menjadi sangat cocok apabila dipergunakan menjadi pijakan dan landasan bagi pengembangan hak-hak perempuan di Indonesia yang sesuai dengan adat dan budaya Indonesia. Berdasarkan pemahaman tentang kedudukan dan posisi perempuan Minangkabau dalam budaya matrilineal inilah, maka gerakan perempuan di Indonesia tidak lagi didominasi oleh gerakan-gerakan dan pemikiran feminis Barat yang belum tentu sesuai dengan alam pikir dan budaya Indonesia, akan tetapi didasari dan dilandasi oleh tata pikir dan alam pikiran khas Indonesia.

\section{SIMPULAN}

Penelitian ini adalah penelitian tentang filsafat Indonesia yang mengambil tema budaya matrilineal dalam masyarakat Minangkabau di wilayah Sumatera Barat yang pada akhirnya membawa pada satu kesimpulan sebagai berikut. 
1. Indonesia adalah negara kepulauan yang besar dengan jumlah penduduk yang sangat banyak dan memiliki adat istiadat serta budaya yang sangat kaya dan beragam. Salah satu budaya yang sangat kaya tersebut adalah budaya matrilineal di Minangkabau Sumatera Barat.

2. Budaya matrilineal pada mulanya dibawa oleh pasukan kerajaan Pagaruyung dengan tujuan untuk menghindari peperangan dengan bala tentara majapahit, yang pada akhirnya berkembang hingga saat ini. Budaya matrilineal di Minangkabau mengandung nilai-nilai filosofis khususnya nilai feminism yaitu bahwa budaya matrilineal memposisikan perempuan menjadi sangat berharga dan menjadikan perempuan memiliki hak-hak penuh di kalangan luar rumah, sehingga para perempuan Minangkabau memiliki kepercayaan diri yang lebih dari pada yang lain.

3. Nilai-nilai yang terkandung dalam budaya matrilineal tersebut yang pada akhirnya memberikan masukan yang bagus untuk gerakan feminis di Indonesia agar mereka memperjuangkan hak-haknya sebagai kaum perempuan dengan berdasar pada budaya lokal, dan bukannya berdasar pada budaya Barat yang pelaksanaannya tidak memiliki kesamaan budaya dengan perempuan Indonesia.

Peneliti sangat memahami bahwa penelitian ini sangat jauh dari sempurna sehingga peneliti bisa memberikan saran kepada penelitipeneliti lain selanjutnya agar bersedia meneliti nilai-nilai dari budaya lokal Indonesia lainnya yang sudah pasti memiliki kesamaan dan kemiripan dengan dasar-dasar karakter masyarakat di Indonesia sehingga akhirnya dapat dijadikan pedoman yang sesuai dengan karakter bangsa dan masyarakat Indonesia.

\section{DAFTAR PUSTAKA}

Alam, Bactiar, 1998, Konsep Kebudayaan Dewasa Ini: Seputar Pertanyaan Mengenai Konstruksi Budaya, Esensialisme dan Kekuasaan. Pokok-pokok Presentasi pada Acara Diskusi Terbatas Asosiasi Antropologi Indonesia (AAI), tanggal 20 Juni 1998 di Depok.

Alam, Bactiar, 1999, “Antropologi dan Civil Society: Pendekatan Teori 
Kebudayaan", Antropologi Indonesia 23(60):3-9.

Barfield, Thomas, 1997, The Dictionary of Anthropology, Blackwell Publishers Inc, Oxford.

Diktat Mata Kuliah Organisasi Sosial dan Sistem Kekerabatan, Jurusan Antropologi FISIP UI. Tidak Diterbitkan.

Ilyas, Yunahar, 2006, Ketaraan Jender dalam Al-Qur'an: Studi Pemikiran Para Mufasir. Penerbit Labda Press, Yogyakarta.

Kymlicka, Will, 2004, Pengantar Filsafat Politik Kontemporer: Kajian Khusus atas Teori-Teori Keadilan, Terjemahan Agus Wahyudi. Penerbit Pustaka Pelajar, Yogyakarta.

Marzali, Amri, 2001, “Dapatkah Sistem Matrilineal Bertahan Hidup di Kota Metropolitan?", Antropologi Indonesia 24(61):1-15.

Murata, Sachiko, 1999, The Tao of Islam, Mizan, Bandung.

Notonagoro, 1968, Pancasila Secara Ilmiah Populer, Fakultas Filsafat UGM, Yogyakarta.

Supadjar, Damardjati, 1993, Nawangsari, MW Mandala, Yogyakarta.

Tong, Rosemarie Putnam, 1998, Feminist Thought: Pengantar Paling Komprehensif kepada Aliran Utama Pemikiran Feminis. Terjemahan Aquarini Priyatna Prabasmoro. Penerbit Jalasutra, Yogyakarta.

\section{Narasumber Wawancara:}

a. Hj. Ermalis

b. Bapak Hefrimon Edy 